FREITAS, Raquel Coelho de. A UNASUL e o papel da democracia nos países da América do Sul. Revista Eletrônica Direito e Política, Programa de Pós-Graduação Stricto Sensu em Ciência Jurídica da UNIVALI, Itajaí, v.11, n.1, $1^{\circ}$ quadrimestre de 2016. Disponível em: www.univali.br/direitoepolitica - ISSN 1980-7791.

\title{
A UNASUL E O PAPEL DA DEMOCRACIA NOS PAÍSES DA AMÉRICA DO SUL
}

\author{
UNASUR AND THE ROLE OF DEMOCRACY IN THE COUNTRIES OF SOUTH \\ AMERICA
}

\section{Raquel Coelho de Freitas ${ }^{1}$}

SUMÁRIO: Introdução; 1 . Os recentes avanços democráticos da região; 2. A solução de alguns páises para os déficits democráticos da região 3 . O modelo de integração política da américa do sul - unasul e a tutela à democracia 4. A utilização do protocolo adicional no caso do paraguai: crise política de 2012; Considerações finais; Referências

\section{RESUMO}

Muitas das constituições latino-americanas refletem o conjunto políticoinstitucional que precisa ser transformado, forçando ainda a cobrança de um modelo democrático mais apropriado para cada país e para a região, com a adoção de mecanismos de democracia mais comunitária e participativa. Essa transformação já pode ser vista em alguns países como o Brasil, Colômbia, Venezuela, Equador, Bolívia e Argentina, onde os institutos de participação popular direta compõem-se ao modelo representativo, ampliando, desse modo, a margem de atuação dos cidadãos nas instâncias consultivas e deliberativas dos poderes institucionalizados. No entanto, esses instrumentos de democracia direta só trazem a eficácia necessária ao exercício da cidadania se as demais esferas constitucionais também forem democratizadas, e no âmbito regional, protegidas. Um passo importante para o fortalecimento da democracia na região foi a construção de integração política denominado União das Nações Sul-Americanas - UNASUL. Com a entrada do Tratado Constitutivo da União de Nações SulAmericanas, em 9 de fevereiro de 2011, foi criado o Protocolo Adicional sobre Compromisso com a Democracia, assinado em novembro de 2010, na Cúpula de Georgetown, tornando-se o primeiro ato normativo em vigor. O Protocolo Adicional cria a chamada "cláusula democrática", por meio da qual os Estados Membros reforçam seu compromisso com a promoção, defesa e proteção da ordem democrática na América do Sul. Neste artigo, o caso do Paraguai será analisado como aferição de eficácia do referido Protocolo e do reforço institucional de democracia para a região.

PALAVRAS-CHAVe: América Latina - Novo Constitucionalismo - Democracia EXclusão - UNASUL

\footnotetext{
${ }^{1}$ Doutora em Direito pela Universidade do Estado do Rio de Janeiro - UERJ; Mestre em Direitos Humanos Internacionais pela Haward Law School, professora do Mestrado em Direito da Universidade Federal do Ceará - UFC. Também professora de Direito Constitucional do Curso de Graduaçao em Direito da UFC. Pesquisadora de vários projetos de pesquisa CAPES e CNPq. Autora de vários capítulos de livros e artigos científicos sobre o tema de Direito Público.
} 
FREITAS, Raquel Coelho de. A UNASUL e o papel da democracia nos países da América do Sul. Revista Eletrônica Direito e Política, Programa de Pós-Graduação Stricto Sensu em Ciência Jurídica da UNIVALI, Itajaí, v.11, n.1, $1^{\circ}$ quadrimestre de 2016. Disponível em: www.univali.br/direitoepolitica - ISSN 1980-7791.

\section{ABSTRACT}

Many Latin American constitutions reflect the political and institutional set that needs to be transformed, even forcing the collection of a more appropriate democratic model for each country and the region, with the adoption of more community and participatory democracy mechanisms. This transformation can already be seen in some countries like Brazil, Colombia, Venezuela, Ecuador, Bolivia and Argentina, where the institutes of direct popular participation make up the representative model, increasing thus the margin of action of citizens in instances advisory and deliberative institutionalized powers. However, such direct democracy instruments only bring efficiency necessary for the exercise of citizenship if the other constitutional spheres are also democratized, and at the regional level, protected. An important step in strengthening democracy in the region was the construction of political integration called the Union of South American Nations - UNASUR. With the entry of the Constitutive Treaty of the Union of South American Nations, on February 9, 2011, the Additional Protocol was created on Commitment to Democracy, signed in November 2010, in the Georgetown Summit, becoming the first normative act into force. The Additional Protocol creates the so-called "democratic clause", whereby Member States strengthen their commitment to the promotion, defense and protection of the democratic order in South America. In this article, the Paraguay case will be analyzed as effective benchmarking of the Protocol and institutional strengthening of democracy in the region.

KEYWORDS: Latin America - New Constitutionalism - Democracy - Exclusion UNASUR

\section{INTRODUÇÃO}

\section{O que a história nos ensinou.}

Os movimentos políticos emergentes na América Latina têm reagido aos estudos sócio-políticos que durante muito tempo apresentaram a região desprovida de uma realização democrática própria, devido às frequentes crises de extrema instabilidade político-institucional na história de cada país que dela faz parte. Essa instabilidade constitucional era apresentada como se os países fossem dotados de total autonomia em seu crescimento doméstico e na consequente realização do seu direito. Talvez até o fossem naquilo que lhes competiu orientar em seu desenvolvimento politico, social e econômico. Mas a história também tem narrado que, apesar da economia nacional dos países latino-americanos ter sido inicialmente controlada por grupos locais, a sua acumulação e expansão não puderam achar seu componente essencial para a dinâmica do crescimento dentro do ambiente interno, devido, principalmente, a influências externas.

Durante as crises que substituíram os governos constitucionais por governos 
FREITAS, Raquel Coelho de. A UNASUL e o papel da democracia nos países da América do Sul. Revista Eletrônica Direito e Política, Programa de Pós-Graduação Stricto Sensu em Ciência Jurídica da UNIVALI, Itajaí, v.11, n.1, $1^{\circ}$ quadrimestre de 2016. Disponível em: www.univali.br/direitoepolitica - ISSN 1980-7791.

militares, os países Latino-Americanos conheceram uma nova teoria de organização do Estado e do direito, a qual consistia na afirmação de uma política de segurança nacional para cada país da região. No Brasil, esta teoria foi desenvolvida, principalmente, pelo Gal. Golbery do Couto e Silva, enquanto no Chile, pelo Gal. Augusto Pinochet Ugarte. A teoria da segurança nacional traduzia-se por escolher a geopolítica como uma estratégia científica de proteção ao território, à soberania e ao povo. Através desta estratégia de guerra, o controle militar sobre a região era justificado, principalmente no combate ao marxismo, ideologia simpatizante dos civis, o que contribuía por instaurar na região, uma cultura de governos fortes.

Devido a esses fatores, o processo de redemocratização da região ocorreu em passos lentos, de liberação gradual de direitos e controle da economia por esses governos de linha autoritária.

A indefinição de um paradigma democrático para a região conduziu o processo de redemocratização dos países latino-americanos para a implementação de ordens liberais e neoliberais em suas constituições. De um modo geral, isso ficou bem evidente nas constantes reformas institucionais que estas constituições sofreram nas últimas três décadas, as quais eram refletidas mais diretamente nas suas ordens jurídicas internas.

Em parte, a estabilidade jurídica de uma sociedade está na forma como a divisão dos direitos e das liberdades é feita na sua constituição, e no relacionamento que esta terá com o Estado. Na outra parte, ela está também na intuição e na prática de cada um em efetivar o direito dentro limites materiais condicionados pelo Estado.

Assim é que, a afirmação da democracia na América Latina passou a requerer mudança de fatores que permitissem um avanço democrático mais significativo. Fatores como patrimonialismo, latifúndio, ausência de distribuição de riquezas, inexperiência com governos democráticos apropriados para a região, importação de valores sócio-jurídicos, dificuldades legais e políticas de se coibir os abusos do poder, dificuldade de uma integração econômica Latino Americana, ou de uma economia que trouxesse benefícios a todos, e a presença de um militarismo 
FREITAS, Raquel Coelho de. A UNASUL e o papel da democracia nos países da América do Sul. Revista Eletrônica Direito e Política, Programa de Pós-Graduação Stricto Sensu em Ciência Jurídica da UNIVALI, Itajaí, v.11, n.1, $1^{\circ}$ quadrimestre de 2016. Disponível em: www.univali.br/direitoepolitica - ISSN 1980-7791.

persistente, comprovaram não apenas os problemas internos de se romper com as elites políticas e econômicas que impediam a ampliação dos benefícios democráticos, como também demonstravam uma dependência maior dos países latino americanos a uma ordem democrática mais globalizada, que precisava ser modificada para atender aos interesses e valores locais.

Na verdade, a democracia, apesar de não ser definida pelo direito, é assegurada por ele e por seus operadores que, ou a efetivam através de um propósito mais racional da lei, ou a inutilizam, desmoronando com isso todo o projeto democrático.

Se o constitucionalismo liberal e neoliberal tem sido uma das características questionáveis do movimento constitucional na América Latina, consequentemente, o modelo inadequado de democracia também o é, apesar de alguns países terem maior experiência democrática do que outros. O limite democrático da região certamente não está na igualdade jurídica assegurada formalmente por suas constituições, ou nos direitos políticos que garantem aos cidadãos a participação política nos pleitos eleitorais, ou ainda na representatividade do povo nas reformas internas. Neste sentido, Guillermo O'Donnell considera que o limite democrático Latino Americano encontra-se na condição difusa de pobreza extrema em que convivem as sociedades, a qual mantém grande parte da população em situação inferior de cidadania, privada de exercer suas potencialidades materiais e humanas, exceto talvez em esferas que se relacionem diretamente com sua própria sobrevivência. ${ }^{2}$ Pois há uma ligação estreita entre constituição, democracia e a igualdade entre indivíduos. E quando uma sociedade é extremamente desigual, a democracia é reduzida a uma aposta coletiva onde a cada cidadão é garantido o mesmo direito de participar na crucial decisão coletiva que determina quem os governará durante certo tempo. Embora de caráter fundamental, essa igualdade política não tem sido legitimada em outros momentos políticos na construção do edifício social de cada país.

\footnotetext{
2 O'DONNELL, Guillermo. Análise do Autoritarismo Burocrático. RJ: Paz e Terra, 1990, p. 39
} 
FREITAS, Raquel Coelho de. A UNASUL e o papel da democracia nos países da América do Sul. Revista Eletrônica Direito e Política, Programa de Pós-Graduação Stricto Sensu em Ciência Jurídica da UNIVALI, Itajaí, v.11, n.1, $1^{\circ}$ quadrimestre de 2016. Disponível em: www.univali.br/direitoepolitica - ISSN 1980-7791.

\section{OS RECENTES AVANÇOS DEMOCRÁTICOS DA REGIÃO.}

Neste contexto de necessidade de avanços político-institucionais e de transformações sociais profundas, é que muitos países latino-americanos tais como Brasil, Colômbia, Venezuela, Equador e Argentina, vêm recriando o papel do Estado nas suas relações com a sociedade. Trata-se de um modelo constitucional que enfatiza a utilidade dos processos constituintes e de democracia participativa para se promover uma democracia avançada, deixando para trás os paradigmas clássicos de Constituições mais liberais, e ampliando o rol de direito das constituições democrático-sociais. O novo paradigma reivindica formas de controle democrático sobre todos os poderes públicos, mecanismos de democracia participativa, propriedade pública das riquezas nacionais, novas formas de redistribuição de riqueza e o mais amplo catálogo de direitos reconhecidos no mundo.

Um dos fundamentos teóricos mais marcantes às inovações constitucionais na América Latina está na força da soberania popular que preexiste a todo tipo de poder estabelecido, capaz de redefinir as relações entre governantes e governados independentemente das normas pré-estabelecidas. Um recente trabalho nesta linha é o dos filósofos Ricardo Sanin e Gabriel Hincapíe, The Encrypted Constitution: A New Paradigm of Oppression, ${ }^{3}$ em que dialogam com os filósofos Étienne Balibar, Alberto Toscano, Michael Hart e Antonio Negri ${ }^{4}$ na tentativa de responder à pergunta de Spinoza sobre qual seria o modo de ação recíproca que caracteriza a existência do corpo político. Para Toscano, por exemplo, a centralidade da democracia é a existência de um corpo político que possui soberania sobre tudo o que está em seu poder, até mesmo uma constituição. Esse exercício do poder soberano do povo acima de toda estrutura de poder é apontado como uma tendência imanente da vida política, ou seja, a

${ }^{3}$ SANIN, Ricardo; HINCAPÍE, Gabriel. La Constitución encriptada. Nuevas

formas de emancipación del poder global. In: http://www.uaslp.mx/Spanish/Academicas/FD/REDHES/Documents/Número\%208/Redhes805.pdf . Acesso em: 15 jan. 2014.

${ }^{4}$ BALIBAR, Étienne. Spinoza. Il transin-dividuale, Milano, Ghibli, 2002; TOSCANO, Alberto. The politics of spinozism - composition and comunication. In: http://criticallegalthinking.com/2012/10/11/the-politics-of-spinozism-1-of-2/ ; HART, Michael y NEGRI, Antonio. Buenos Aires: Editorial Paidós, 2005. 
FREITAS, Raquel Coelho de. A UNASUL e o papel da democracia nos países da América do Sul. Revista Eletrônica Direito e Política, Programa de Pós-Graduação Stricto Sensu em Ciência Jurídica da UNIVALI, Itajaí, v.11, n.1, $1^{\circ}$ quadrimestre de 2016. Disponível em: www.univali.br/direitoepolitica - ISSN 1980-7791.

verdade de toda ordem política, a qual pode ser vista também nos trabalhos de autores como Hart e Negri. ${ }^{5}$

Ricardo Sanin e Gabriel Hincapíe reconhecem que a democracia é o paradoxo da política, pois somente na democracia o ato de governar e ser governado recai sobre o mesmo sujeito. Em uma oligarquia ou em uma aristocracia, por exemplo, a existência e posição do governado estão definidas por quem governa segundo uma distribuição natural do poder, isto é, é natural que o forte comande ao débil, o sábio, ao ignorante etc. Portanto, não se poderia falar de conflito em relações oligárquicas ou aristocráticas, uma vez que o conflito já existiu, e só não se perpetua porque há uma acomodação de uma forma concreta de legalidade que reflete o domínio de uma classe sobre outra, onde o conflito já teria sido resolvido a favor dos governantes. Nem mesmo a comunidade teria acesso a essa relação, pois esta se encontra dividida entre uma classe que tem acesso à política, por uma condição natural, e outra sujeita a este domínio.

Um forte inspirador à posição de Ricardo Sanin e Gabriel Hincapíe é o filósofo francês Jacques Ranciere ${ }^{6}$, que entende que na democracia, o sujeito se define a si mesmo, a partir do seu lugar central na atividade política. Pois como ressaltam os autores, a democracia rompe com duas lógicas: a da separação absoluta entre governante e governado, e a da ideia segundo a qual todo tipo de distribuição de poder requer um modelo pré-existente. Em outras palavras, a democracia rompe com a lógica de que nas normas para governar está o requerimento natural para poder governar. Para Jacques Ranciere, a democracia é precisamente a anulação das condições para governar; é o governo daqueles que carecem de qualidades ou disposições para governar.

Neste contexto, o liberalismo político ao inserir nas constituições apenas um modelo de democracia representativa, sem assegurar a legitimidade dessa representação, teria neutralizado a própria democracia. Pois é na construção da

\footnotetext{
${ }^{5}$ BALIBAR, Étienne. Spinoza. Il transin-dividuale, Milano, Ghibli, 2002; TOSCANO, Alberto. The politics of spinozism - composition and comunication. In: http://criticallegalthinking.com/2012/10/11/the-politics-of-spinozism-1-of-2/ ; HART, Michael y NEGRI, Antonio. Buenos Aires: Editorial Paidós, 2005.
}

${ }^{6}$ RANCIERE, Jacques. Ten thesis on politics. Baltimore: John Hopkins Univesety Press, 2001 
FREITAS, Raquel Coelho de. A UNASUL e o papel da democracia nos países da América do Sul. Revista Eletrônica Direito e Política, Programa de Pós-Graduação Stricto Sensu em Ciência Jurídica da UNIVALI, Itajaí, v.11, n.1, $1^{\circ}$ quadrimestre de 2016. Disponível em: www.univali.br/direitoepolitica - ISSN 1980-7791.

democracia Liberal que as constituições são encriptadas, e a democracia passa a ser definida a partir das condições estabelecidas para se governar, ou seja, a partir do que é absolutamente alheio à sua construção ontológica.

De fato, o embate maior observado nas manifestações políticas nos países com democracias liberais refere-se ao exercício da soberania popular sobre políticas públicas, ou mesmo sobre as normas constitucionais que não traduzem a vontade popular. O que fazer quando a constituição parece engessada e não permite as mudanças institucionais necessárias, nem mesmo por meio do exercício da soberania popular, como foi o caso da crise constitucional de Honduras em 2009, que levou ao enfrentamento entre soberania popular e normas rígidas constitucionais, sem possibilidade de alteração? ${ }^{7}$

Há nas manifestações políticas um distanciamento notório das instituições de caráter representativo na região. Muitas das manifestações políticas têm sido conduzidas por jovens sem muita experiência política ou ligação políticopartidária, ou com lideranças políticas fortes, ou ideologias bem sedimentadas. $\mathrm{Na}$ maioria das vezes, os manifestantes sequer conduzem suas demandas para os canais institucionais, como os partidos políticos e órgãos de representação política, o que indica que essa concepção teórica encontra algumas premissas de verdade quando reforça o papel da soberania popular.

Se por um lado a democracia deve ser respaldada na força da soberania popular, por outro, ela necessita do modelo constitucional para efetivá-la dentro de parâmetros mais seguros. Caso contrário, dois riscos podem surgir: o primeiro, de se considerar que o Estado de Direito por não falar a linguagem da democracia, deveria ter seus limites político-institucionais reduzidos à forma como a democracia se manifesta, ficando sempre submetido a ela. O segundo, de uma consequente necessidade de se reforçar a presença de governos autoritários fortes, para se controlar os excessos que surjam na ausência de limites legais constitucionais, como no caso dos militares, que ainda são muito emergentes na América Latina, frequentemente invocados para conter

\footnotetext{
7 In: http://pt.euronews.com/2009/10/08/impasse-politico-nas-honduras-parece-estar-para-durar/ . Acesso em: 15 jan. 2014.
} 
FREITAS, Raquel Coelho de. A UNASUL e o papel da democracia nos países da América do Sul. Revista Eletrônica Direito e Política, Programa de Pós-Graduação Stricto Sensu em Ciência Jurídica da UNIVALI, Itajaí, v.11, n.1, $1^{\circ}$ quadrimestre de 2016. Disponível em: www.univali.br/direitoepolitica - ISSN 1980-7791.

movimentos políticos anárquicos, algumas vezes confundidos com atos violentos, sem causa.

Enquanto o primeiro risco pode ser atenuado pela possibilidade de reformas políticas com reforço à soberania popular, que os manifestantes tentam aprimorar, o segundo parece mais preocupante, pois tende a compreender as manifestações políticas como atos de ameaça à ordem, e, portanto, à soberania nacional, e não como atos de legitimidade política.

A solução para essa crise, que incluiria uma contenção militar e uma ampliação das possibilidades institucionais de manifestações legítimas fora do âmbito institucional, está na reconciliação necessária e urgente da democracia com a constituição. A democracia surge aqui como um poder atribuído ao povo de eleger seus representantes, de participar das decisões sobre investimentos públicos, e de cobrar deles uma prestação de contas pelo mau uso do seu mandato, por meios mais participativos e diretos. Antes de ser temido e inviabilizado, esse deve ser um projeto regulamentado e adaptado às tecnologias atuais.

Paradoxalmente, a maioria dos projetos de democracia e de participação popular nas constituições contemporâneas ainda traz em si a proposta de limitar esse poder de decisão do povo em conteúdo e procedimentos. Por isso, é fundamental que a constituição seja, antes de tudo, democrática, com instrumentos e procedimentos de exercício do poder soberano, e com possibilidades de alterações que visem o seu constante aprimoramento. Se ela não inviabilizar o projeto democrático participativo e aberto a mudanças, tem mais chances de funcionar e impedir que movimentos com características sem causa, possam, de fato, emergir.

A busca ao equilíbrio para essa crise político-institucional inicia-se por se considerar que as manifestações atuais devem ser pensadas quanto à natureza de suas reivindicações, as quais traduzem uma insatisfação profunda com as instituições representativas. Por sua vez, também recai sobre um problema de ordem global que envolve sérias contradições com o modelo histórico excludente que muito influenciou a afirmação das liberdades nas Constituições latino- 
FREITAS, Raquel Coelho de. A UNASUL e o papel da democracia nos países da América do Sul. Revista Eletrônica Direito e Política, Programa de Pós-Graduação Stricto Sensu em Ciência Jurídica da UNIVALI, Itajaí, v.11, n.1, $1^{\circ}$ quadrimestre de 2016. Disponível em: www.univali.br/direitoepolitica - ISSN 1980-7791.

americanas. Embora a afirmação dessas liberdades estivesse presente nessas Constituições do final do século passado, a maioria da população dos países de formação étnica indígena ou afrodescendente ainda permanecia excluída de direitos e garantias constitucionais, sofrendo graves consequências de desigualdade social.

A partir da década de 80 , por exemplo, os povos indígenas da América Latina começaram a externalizar a consciência do seu estado de exclusão da esfera política e social no Estado e a buscar, de forma mais organizada, uma participação inclusiva nos assuntos públicos. Nesse momento, os indígenas foram articulando-se em movimentos sociais na busca por direitos específicos, como os direitos sociais à educação e à saúde, bem como o direito ao reconhecimento de suas identidades étnicas pelo Estado, dentro das políticas públicas. Como exemplo, há as lutas dos indígenas ou descendentes de indígenas na Bolívia, como A Marcha pelo Território, a Dignidade e a Vida; a Defesa da Água em Cochabamba; e a luta em Defesa do Gás, que ampliaram e fortaleceram a necessidade de inclusão de todos aqueles sujeitos interessados na gestão pública sobre os recursos naturais, entre outras.

No Brasil, a primeira década deste século foi marcada pela insurgência forte do movimento negro por uma maior inclusão dos afrodescendentes nas políticas públicas de distribuição de direitos, bens e outros recursos, em particular, na educação superior, e outros direitos previstos para todos na Constituição democrática de 1988.

Com isso, tornou-se crescente e pacífico o entendimento de que os modelos constitucionais de final do século passado e início do século XXI não traziam a tutela constitucional necessária e adequada à realidade dos grupos subrepresentados politicamente nos países da América Latina. Em particular, porque o projeto de inclusão enfatizava diferenças e não promovia, necessariamente, mudanças institucionais para a ampliação da diversidade cidadã. O modelo de economia e desenvolvimento, por exemplo, não respondia às demandas por igualdade e inclusão, enquanto o sistema da democracia representativa apresentava-se cada vez mais simbólico e distante dos anseios populares, silenciando a opressão por meio da institucionalização da corrupção e 
FREITAS, Raquel Coelho de. A UNASUL e o papel da democracia nos países da América do Sul. Revista Eletrônica Direito e Política, Programa de Pós-Graduação Stricto Sensu em Ciência Jurídica da UNIVALI, Itajaí, v.11, n.1, $1^{\circ}$ quadrimestre de 2016. Disponível em: www.univali.br/direitoepolitica - ISSN 1980-7791.

beneficiamentos a empresas privadas em detrimento dos interesses públicos. ${ }^{8}$

A segunda contradição está nas consequências das políticas neo-liberais. Quando muitos países foram redemocratizados na década de 1990, sofreram uma imposição neoliberal de privatizações dos serviços públicos essenciais, como saúde, educação, água, energia, infraestrutura, transporte, etc., a fim de reduzir gastos do estado. Alinhado a isso estava o tradicional modelo de democracia liberal que reduziu drasticamente o poder de intervenção dos cidadãos nas esferas deliberativas sobre esses serviços. Com isso, as demandas por qualidade de vida, tornaram-se questões de consumo. Como nem as promessas de qualidade de vida, nem as de consumo chegaram à grande maioria das pessoas, as políticas neoliberais resultaram desacreditadas e, consequentemente, deslegitimadas. Se esse projeto estivesse dando certo, as sociedades não estariam confinadas em classes ou castas protegidas, vivendo em zonas de conforto cada vez mais isoladas e silenciosas, inconformadas, apenas com ameaças a sua proteção, segurança e bem-estar. Por outro lado, não haveria classes ou castas também confinadas, porém, resignadas a um projeto de emancipação humana sem esperança. Mais ainda, não havia minorias excluídas.

Ainda que os direitos sejam garantidos a todos nessas constituições, na prática, eles sofreram um esvaziamento que limitou a sua realização coletiva, o que enfraquece a proteção constitucional igualitária e emancipatória. Sem condições e oportunidades iguais e reais, o projeto de democracia representativa entra em colapso e as pessoas buscam outras alternativas de demonstração das suas insatisfações com o poder público. Assim, difícil pensar em manifestações anárquicas, ou mesmo de quebra de normas legais desses movimentos, sem associá-los à quebra de normas morais e jurídicas do estado.

O que se observa nos movimentos políticos, é que o modelo democrático

\footnotetext{
${ }^{8}$ FAGUNDES, Lucas Machado, "Reflexões sobre o processo constituinte Boliviano e o Novo Constitucionalismo Sul-Americano". In: WOLKMER, Antônio Carlos e PETTERS MELO, Milena (Orgs.), Constitucionalismo Latino Americano, tendências contemporânes. Curitiba: Juruá, 2013. Veja, também, neste sentido, NOGUERA FERNÁNDEZ, A. Constitución, plurinacionalidad y pluralismo jurídico en Bolivia. Oxfam GranBretaña, La Paz: 1a. Edición, Colección Enlaces, 2008.
} 
FREITAS, Raquel Coelho de. A UNASUL e o papel da democracia nos países da América do Sul. Revista Eletrônica Direito e Política, Programa de Pós-Graduação Stricto Sensu em Ciência Jurídica da UNIVALI, Itajaí, v.11, n.1, $1^{\circ}$ quadrimestre de 2016. Disponível em: www.univali.br/direitoepolitica - ISSN 1980-7791.

representativo $^{9}$ passou a ser denunciado pela sua falta de legitimidade, de consentimento das pessoas realmente interessadas, e pelo distanciamento dessas pessoas na tomada de decisões sobre assuntos de interesse geral. Em outras palavras, a herança de exclusão e marginalização combinada com as mais recentes receitas privatistas do modelo neoliberal, implementadas em vários países Latino Americanos, trataram os seus problemas estruturais de modo formal, vazio de participação e, portanto, de legitimidade.

Quando esse distanciamento associou-se a práticas de corrupção, ausência de transparência na gestão pública, projetos contrários aos anseios populares, propaganda enganosa do governo, a crise agravou-se e a insatisfação dos cidadãos tomou novos formatos e conteúdos para além da inclusão das minorias étnico-raciais, com uma permanente denúncia de crise de representatividade, e, consequentemente, de governabilidade.

\section{A SOLUÇão DE ALGUNS PÁISES PARA OS DÉfICITS DEMOCRÁTICOS DA REGIÃo.}

Maxwel Cameron aponta três importantes déficits democráticos na região. ${ }^{10} \mathrm{O}$ primeiro deles refere-se à tirania das maiorias, muito utilizada nas teorias democráticas liberais com o intuito de legitimar o exercício das liberdades pelas elites econômicas e políticas, em oposição aos exercícios da soberania popular. O segundo déficit está em se reconhecer que a democracia representativa não tem sido o melhor modelo para combater as desigualdades sociais. As eleições tendem a criar e perpetuar elites políticas, alinhadas, muitas vezes, às elites econômicas e outros setores privilegiados da sociedade. ${ }^{11} \mathrm{O}$ terceiro déficit expõe

\footnotetext{
9 UBINATI, Nadia. Representative Democracy: Principles and Genealogy. Chicago: The University of Chicago Press, 2008.

10 CAMERON, Maxwel. New Mechanisms of Democratic Participation in Latin America. LASAFORUM, Winter 2014 : volume xIv : issue 1. Disponível em: http://lasa.international.pitt.edu/forum/files/vol45-issue1/Debates2.pdf ; Acesso em: 20/01/2014

${ }^{11}$ Cf: Sobre o assunto, veja recente pesquisa de SARMENTO, Daniel e OSORIO, Aline. Eleições, Dinheiro e Democracia: A ADI 4.650 e o modelo brasileiro de financiamento de campanhas eleitorais. Disponível em: http://www.oab.org.br/arquivos/artigo-adi-4650-362921044.pdf ; acessível em: 18/01/2014.
} 
FREITAS, Raquel Coelho de. A UNASUL e o papel da democracia nos países da América do Sul. Revista Eletrônica Direito e Política, Programa de Pós-Graduação Stricto Sensu em Ciência Jurídica da UNIVALI, Itajaí, v.11, n.1, $1^{\circ}$ quadrimestre de 2016. Disponível em: www.univali.br/direitoepolitica - ISSN 1980-7791.

a formação de uma cidadania passiva. Como a democracia representativa não requer participação e deliberação em assuntos coletivos, apenas participação pontual e individual no ato de votar, desenvolve-se, naturalmente, um enfraquecimento na cidadania. Sem esses mecanismos de participação, os cidadãos ficam sem voz, sem atuação, e desengajados das decisões públicas que os afetam mais diretamente. Certamente, o constrangimento maior ocorre para as comunidades indígenas com fortes tradições no exercício do poder coletivo na tomada de decisões.

Assim é que a observância desses movimentos não deve ser apenas quanto aos caminhos de estruturação, mas, principalmente, quanto ao tipo de insatisfação social que expressam, pela possibilidade de resposta institucional que possam obter, quer através de reformas políticas, ou de transformações estruturais mais gerais.

Na América Latina a resposta tem sido diferente. Tem sido a busca pela reconstrução dos Estados com institutos políticos, econômicos e jurídicos mais democráticos, com a necessária mudança no modelo de democracia representativa. Isso tem ocorrido em países como o Brasil, Colômbia, Venezuela, Equador, Bolívia e Argentina, onde os institutos de participação popular direta compõem-se ao modelo representativo, ampliando, desse modo, a margem de atuação dos cidadãos das instâncias deliberativas dos poderes institucionalizados. No caso da Constituição da Bolívia de 2009, por exemplo, onde o modelo é híbrido complementar, adota três formas de democracia: democracia representativa, que vem complementada por mecanismos de democracia direta e participativa, com equivalência de condições entre homens e mulheres, e a democracia comunitária. No entanto, esses instrumentos de democracia direta só trazem a eficácia necessária ao exercício da cidadania se as demais esferas constitucionais também forem democratizadas.

Essas mudanças estão muito presentes na modalidade da democracia comunitária, que expressa a adequação necessária ao modelo plural de Estado, exercida por meio de eleição, designação ou nomeação de autoridades e representantes por normas e procedimentos próprios das nações e povos 
FREITAS, Raquel Coelho de. A UNASUL e o papel da democracia nos países da América do Sul. Revista Eletrônica Direito e Política, Programa de Pós-Graduação Stricto Sensu em Ciência Jurídica da UNIVALI, Itajaí, v.11, n.1, $1^{\circ}$ quadrimestre de 2016. Disponível em: www.univali.br/direitoepolitica - ISSN 1980-7791.

indígenas 'originário camponeses', entre outros, conforme regulamentação em lei.

A modalidade de democracia comunitária reflete 0 reconhecimento da legitimidade de novos sujeitos na construção da vontade nacional, e de sua afirmação de cidadania constitucional, com a opção que o poder constituinte fez em reorganizar o Estado em bases mais democráticas, no caso, plurinacionais, com o fim de suprir a fórmula esgotada da combinação hegemônica moderna: para cada Estado - Uma Nação; e também do esgotamento do sistema representativo de democracia, o qual teria que prever sistemas de participação adequada aos novos sujeitos coletivos, a partir de suas experiências deliberativas comuns.

Desse modo, o modelo de democracia híbrida complementar na Bolívia tornouse o resultado da necessidade de reordenação do espaço público em moldes mais inclusivos através da conversão da exclusão indígena em poder cidadão institucional, e, consequentemente, com novos sujeitos que possam estar, de fato, inseridos nas tradicionais instâncias decisórias do Estado. A demanda por valorização cultural com a proteção da identidade desses grupos, por novas políticas sócio-econômicas, e de participação popular foi fundamental para que o Estado pudesse definir o tipo de resposta a oferecer.

E que modelo democrático seria ideal para respondermos às demandas dos movimentos políticos na região?

\section{O MOdelo de INTEgRAÇÃo POLÍtica dA AMÉRICA do SUL - UNASUL E A TUTELA À DEMOCRACIA}

Muitas das constituições latino americanas refletem o conjunto políticoinstitucional que precisa ser transformado, forçando ainda a cobrança de um modelo democrático mais apropriado para cada país, com a adoção de mecanismos de democracia mais comunitária e participativa. ${ }^{12}$ Pois quando

12 Cf. ACEMOGLU, Daron; JOHNSON, Simon y ROBINSON, James 2001 "The Colonial Origins of Comparative Development: An Empirical Investigation" In: American Economic Review. December, 91, 5, pet al., 2004: 5, p. 1.401. Discussão sobre o tema em SUÁREZ, Elena Patricia 
FREITAS, Raquel Coelho de. A UNASUL e o papel da democracia nos países da América do Sul. Revista Eletrônica Direito e Política, Programa de Pós-Graduação Stricto Sensu em Ciência Jurídica da UNIVALI, Itajaí, v.11, n.1, $1^{\circ}$ quadrimestre de 2016. Disponível em: www.univali.br/direitoepolitica - ISSN 1980-7791.

democráticas, as constituições trazem a expressão dos mais diferentes interesses, considerando sempre o nível de dependência econômica para a realização desses direitos, bem como o conjunto de mecanismos democráticos que permitam aos cidadãos defendê-los, em particular, de toda norma que possa reduzir o conceito de democracia às regras de mercado e à reprodução de desigualdades. ${ }^{13}$

Um passo importante para o fortalecimento da democracia na região foi a construção do novo modelo de integração política denominado União das Nações Sul-Americanas - UNASUL, criada paralelamente à comunidade Andina de Nações (CAN), e ao Mercado Comum do Sul - MERCOSUL, que colocaram em prática a Zona de Livre Comércio entre seus membros, nos pólos opostos da América do Sul.

A UNASUL foi criada com o objetivo de alcançar a integração dos países da América do Sul - Argentina, Bolívia, Brasil, Chile, Colômbia, Equador, Guiana, Paraguai, Peru, Suriname, Uruguai e a Venezuela, não apenas no plano econômico, mas também, político, cultural e social. No plano econômico, o objetivo maior da União é a criação de uma zona de livre comercio que possa abrigar o Mercado Comum do Sul - MERCOSUL e a Comunidade Andina de Nações-CAN, além da Guiana e do Suriname, no modelo da União Europeia. No plano político, a UNASUL visa estabelecer parâmetros comuns de democracia que tragam a proteção necessária para a estabilidade político-institucional da região. Através desse espaço de integração econômica e política, a UNASUL busca o desenvolvimento de mecanismos concretos e efetivos para a superação de assimetrias culturais, sociais, econômicas e políticas entre os países, além de ampliar as formas de diálogo na região e fortalecer os objetivos de crescimento econômico e alargamento democrático próprio, conforme consta no seu Tratado Constitutivo da União de Nações Sul-Americanas, no seu art. $2^{\circ}$ :

A União de Nações Sul-americanas tem como objetivo construir, de maneira participativa e consensuada, um

Suárez. "El proceso de cambio en Bolivia". In: Crítica y Emancipación No 10, Revista Latinoamericana de Ciencias Sociales (Segundo Semestre 2013).

13 SUÁREZ, Elena Patricia Suárez ( 2013), pag. 235. 
FREITAS, Raquel Coelho de. A UNASUL e o papel da democracia nos países da América do Sul. Revista Eletrônica Direito e Política, Programa de Pós-Graduação Stricto Sensu em Ciência Jurídica da UNIVALI, Itajaí, v.11, n.1, $1^{\circ}$ quadrimestre de 2016. Disponível em: www.univali.br/direitoepolitica - ISSN 1980-7791.

espaço de integração e união no âmbito cultural, social, econômico e político entre seus povos, priorizando o diálogo político, as políticas sociais, a educação, a energia, a infraestrutura, o financiamento e o meio ambiente, entre outros, com vistas a eliminar a desigualdade socioeconômica, alcançar a inclusão social e a participação cidadã, fortalecer a democracia e reduzir as assimetrias no marco do fortalecimento da soberania e independência dos Estados.

No plano politico-institucional, o objetivo maior é o fortalecimento da democracia, da soberania e independência dos Estados. Neste sentido, alguns países da UNASUL estão recriando o papel do Estado nas suas relações com a sociedade através da consolidação da ideia da soberania popular e participação popular, a qual impõe uma releitura do constitucionalismo clássico representativo, de modo que os direitos fundamentais e as garantias inseridas nas constituições dos países da região possam ser interpretadas de modo a prestigiar os valores democraticamente eleitos pelo legislador constituinte. Dentre esses valores estão o desenvolvimento, a paz e a busca pela estabilidade das instituições, os quais, para serem alcançados, implicam na participação de vários atores, por meio de mecanismos de interação e dialogo na formulação de políticas de integração. Essas políticas tem tido uma concentração maior nos segmentos de educação, cultura, infraestrutura, energia, ciências e finanças.

Neste sentido, dentre os objetivos específicos da UNASUL, encontram-se:

O desenvolvimento social e humano com equidade e inclusão para erradicar a pobreza e superar as desigualdades na região;

A erradicação do analfabetismo, o acesso universal a uma educação de qualidade e o reconhecimento regional de estudos e títulos;

A integração energética para o aproveitamento integral, sustentável e solidário dos recursos da região;

O desenvolvimento de uma infraestrutura para a interconexão da região e de nossos povos de acordo com critérios de desenvolvimento social e econômico sustentáveis; 
FREITAS, Raquel Coelho de. A UNASUL e o papel da democracia nos países da América do Sul. Revista Eletrônica Direito e Política, Programa de Pós-Graduação Stricto Sensu em Ciência Jurídica da UNIVALI, Itajaí, v.11, n.1, $1^{\circ}$ quadrimestre de 2016. Disponível em: www.univali.br/direitoepolitica - ISSN 1980-7791.

A integração financeira mediante a adoção de mecanismos compatíveis com as políticas econômicas e fiscais dos Estados Membros;

A proteção da biodiversidade, dos recursos hídricos e dos ecossistemas, assim como a cooperação na prevenção das catástrofes e na luta contra as causas e os

A consolidação de uma identidade sul-americana através do reconhecimento progressivo de direitos a nacionais de um Estado Membro residentes em qualquer outro Estado Membro, com o objetivo de alcançar uma cidadania sulamericana;

O acesso universal à seguridade social e aos serviços de saúde;

A cooperação em matéria de migração, com enfoque integral e baseada no respeito irrestrito aos direitos humanos e trabalhistas para a regularização migratória e a harmonização de políticas;

O integração industrial e produtiva, com especial atenção às pequenas e médias empresas, cooperativas, redes e outras formas de organização produtiva;

A definição e implementação de políticas e projetos comuns ou complementares de pesquisa, inovação, transferência e produção tecnológica, com vistas a incrementar a capacidade, a sustentabilidade e o desenvolvimento científico e tecnológico próprios;

A promoção da diversidade cultural e das expressões da memória e dos conhecimentos e saberes dos povos da região, para o fortalecimento de suas identidades;

A participação cidadã, por meio de mecanismos de interação e diálogo entre a UNASUL e os diversos atores sociais na formulação de políticas de integração sul-americana;

A coordenação entre os organismos especializados dos Estados Membros, levando em conta as normas internacionais, para fortalecer a luta contra o terrorismo, a corrupção, o problema mundial das drogas, o tráfico de pessoas, o tráfico de armas pequenas e leves, o crime organizado transnacional e outras ameaças, assim como para promover o desarmamento, a não proliferação de armas nucleares e de destruição em massa e a desminagem;

A promoção da cooperação entre as autoridades judiciais dos Estados Membros da UNASUL; 
FREITAS, Raquel Coelho de. A UNASUL e o papel da democracia nos países da América do Sul. Revista Eletrônica Direito e Política, Programa de Pós-Graduação Stricto Sensu em Ciência Jurídica da UNIVALI, Itajaí, v.11, n.1, $1^{\circ}$ quadrimestre de 2016. Disponível em: www.univali.br/direitoepolitica - ISSN 1980-7791.

Com a entrada do Tratado Constitutivo da União de Nações Sul-Americanas, em 9 de fevereiro de 2011, após o nono instrumento de ratificação depositado pelo Uruguai, o criado o primeiro ato normativo Protocolo Adicional ao Tratado Constitutivo da UNASUL sobre Compromisso com a Democracia, assinado em novembro de 2010, na Cúpula de Georgetown. O Protocolo Adicional, além de expressar a importância de se assegurar uma estabilidade democrática aos países da região, em particular, àqueles que inseriram em suas constituições mecanismos de democracia direta, participativa e comunitária, cria a chamada "cláusula democrática", por meio da qual os Estados Membros reforçam seu compromisso com a promoção, defesa e proteção da ordem democrática de toda a América do Sul, tanto no âmbito interno dos Estados, como na UNASUL.

De acordo com os seus objetivos, o tratado compromete os países membros da UNASUL à promoção, defesa e proteção da ordem democrática, do Estado de Direito e suas instituições, dos Direitos Humanos e liberdades fundamentais, incluindo a liberdade de opinião e de expressão, como condição essencial e indispensável para o desenvolvimento do processo de integração, e requisito essencial para a própria participação na UNASUL.

De acordo com o artigo 40, o Protocolo será aplicado em caso de ruptura ou ameaça de ruptura da ordem democrática, de uma violação da ordem constitucional ou em qualquer situação que ponha em risco o legítimo exercício do poder e a vigência da ordem democrática estabelecida nas constituições dos países membros.

Artigo 4 - O Conselho de Chefes de Estado e de Governo, ou na falta deste, o Conselho de Ministros das Relações Exteriores, poderá estabelecer, em caso de ruptura ou ameaça de ruptura da ordem democrática, entre outras, as medidas detalhadas abaixo, destinadas a restabelecer o processo político institucional democrático. Estas medidas entrarão em vigor na data de adoção da respectiva decisão.

a. - Suspensão do direito de participar nos diferentes órgãos e instâncias da UNASUL, bem como do gozo dos direitos e prerrogativas decorrentes do Tratado 
FREITAS, Raquel Coelho de. A UNASUL e o papel da democracia nos países da América do Sul. Revista Eletrônica Direito e Política, Programa de Pós-Graduação Stricto Sensu em Ciência Jurídica da UNIVALI, Itajaí, v.11, n.1, $1^{\circ}$ quadrimestre de 2016. Disponível em: www.univali.br/direitoepolitica - ISSN 1980-7791.

Constitutivo da UNASUL ${ }^{14}$.

b. - Fechamento parcial ou total das fronteiras terrestres, incluindo a suspensão e/ou limitação do comércio, transporte aéreo e marítimo, comunicações, fornecimento de energia, serviços e abastecimento.

c. - Promover a suspensão do Estado afetado no âmbito de outras organizações regionais e internacionais.

d. - Promover, ante terceiros países e/ou blocos regionais, a suspensão dos direitos e/ou prerrogativas do Estado afetado derivados dos acordos de cooperação em que seja parte.

e. - Adoção de sanções políticas e diplomáticas adicionais

O Protocolo Adicional demonstra, desse modo, a preocupação que o bloco tem em manter a democracia vigente. Assim é que estabelece como condição de obter essa proteção interna, a participação do país membro na UNASUL.

\section{A UTILIZAÇÃO DO PROTOCOLO ADICIONAL NO CASO DO PARAGUAI: CRISE POLÍTICA DE 2012}

Em 15 de agosto de 2008, Fernando Lugo assumiu, democraticamente, o cargo de Presidente da República do Paraguai, rompendo, com a hegemonia do Partido Colorado que permaneceu mais de 60 anos ininterruptos no poder. A eleição de Lugo fez renascer na população paraguaia um sentimento nacionalista e a esperança de mudanças concretas que favorecessem a população mais pobre.

Ex-bispo da Igreja Católica, Fernando Lugo, conhecido como o "bispo dos pobres", esteve à frente de diversas manifestações sociais de protesto contra o governo, sendo a principal delas contra a reeleição do presidente Nicanor Duarte em 2006. Foi o candidato à presidência do partido "Aliança Patriótica para a Mudança" que reunia os partidos de esquerda e centro-esquerda do país. O apoio do Partido Liberal Radical Autêntico, segundo maior partido do Paraguai, foi

${ }^{14}$ SUÁREZ, Elena Patricia Suárez ( 2013), pag. 235. 
FREITAS, Raquel Coelho de. A UNASUL e o papel da democracia nos países da América do Sul. Revista Eletrônica Direito e Política, Programa de Pós-Graduação Stricto Sensu em Ciência Jurídica da UNIVALI, Itajaí, v.11, n.1, $1^{\circ}$ quadrimestre de 2016. Disponível em: www.univali.br/direitoepolitica - ISSN 1980-7791.

decisivo para a sua vitória. Contudo, é interessante ressaltar que o vicepresidente de Lugo, Federico Franco, é filiado ao Partido Liberal Radical Autêntico, o que explica o apoio recebido por este Partido.

O Partido Colorado, conhecendo o favoritismo de Fernando Lugo à época, questionava a legalidade de sua candidatura, pois a Constituição Nacional é clara ao impedir ministros de qualquer religião de exercer a presidência do país ${ }^{15}$. Por este motivo, Lugo fez um pedido de renúncia ao seu estado eclesial que foi rejeitado pelo Papa Bento XVI. Somente em 2008, o Papa aceitou a renúncia de Fernando Lugo.

\section{4.a. O PRESIDENTE SOLITÁRIO}

Acredita-se que a falta de experiência política trouxe um obstáculo pertinente ao então recém-nomeado presidente Fernando Lugo. Sua participação em movimentos populares contra o antigo governo vigente, dominado pelo Partido Colorado, não agradava a grande maioria dos parlamentares, que eram colorados.

Durante seu mandato, Lugo não se preocupou em fazer alianças políticas para conseguir enfrentar a forte oposição dos congressistas que se manifestaram quatro anos depois de ser eleito. A imensa rejeição ao seu governo foi comprovada quando a Câmara dos Deputados aprovou a abertura do processo de impeachment de Fernando Lugo, obtendo de pronto, o apoio da maioria do Congresso.

Esta não foi a primeira vez que os opositores parlamentares falaram em destituir Fernando Lugo do poder. Em 2009, rumores já circulavam indicando que o

${ }^{15}$ PARAGUAI. Constituição (1992). Constituição da República do Paraguai. Disponível em: $<$ http://www.icrc.org/ihl-

nat.nsf/162d151af444ded44125673e00508141/70fa4404138f6d39c12570530030067c/\$FILE/Const itucion.Paraguay.ESP.pdf>. Acesso em: 30 set. 2012.

\section{Artículo 235 - DE LAS INHABILIDADES}

Son inhábiles para ser candidatos a Presidente de la República o Vicepresidente:

5. los ministros de cualquier religión o culto; 
FREITAS, Raquel Coelho de. A UNASUL e o papel da democracia nos países da América do Sul. Revista Eletrônica Direito e Política, Programa de Pós-Graduação Stricto Sensu em Ciência Jurídica da UNIVALI, Itajaí, v.11, n.1, $1^{\circ}$ quadrimestre de 2016. Disponível em: www.univali.br/direitoepolitica - ISSN 1980-7791.

Congresso tentaria retirá-lo do poder de forma constitucional para evitar, assim, revoluções internas ou externas. O Partido Liberal Radical Autêntico (PLRA), aliando-se ao Partido Colorado, impetraria o impeachment contra Lugo e, quando este fosse deposto, Federico Franco assumiria a presidência.

É incontestável afirmar que a relação entre o presidente e os demais políticos paraguaios era bastante complexa e imprevisível. Os quase quatro anos em que esteve no poder foram suficiente para Fernando Lugo desagradar uma quantidade considerável de poderosos e ferir inúmeros interesses políticos com suas decisões e medidas radicais.

As divergências políticas alcançaram seu ponto máximo quando Lugo tentou implantar a reforma agrária no país, medida que foi recebida com desprezo pelos deputados e senadores, grande parte proprietários de latifúndios. Outra medida que muito desagradou a direita política do país foi a tentativa de aprovação do projeto de renda mínima que utilizaria parte dos lucros de Itaipu para beneficiar 85 mil famílias que viviam em situação de pobreza Este projeto foi logo vetado pelo Congresso.

O confronto de vontades políticas também se fez presente entre o presidente e o seu vice. Ambos não conseguiam chegar a um consenso sobre quais políticas públicas deveriam ser prioridade para promover o desenvolvimento social e a institucionalização da democracia no Paraguai, fato este que muito enfraqueceu a relação entre os dois e também o apoio do PLRA ao governo de Lugo.

Finalmente, o julgamento político contou com cinco deputados que apresentaram cinco motivos para destituir Fernando Lugo. De acordo com a Constituição Paraguaia $^{16}$, o presidente pode sofrer impedimento de seu mandato pelo

\footnotetext{
${ }^{16}$ Artículo 225 - DEL PROCEDIMIENTO

El Presidente de la República, el Vicepresidente, los ministros del Poder Ejecutivo, los ministros de la Corte Suprema de Justicia, el Fiscal General del Estado, el Defensor del Pueblo, el Contralor General de la República, el Subcontralor y los integrantes del Tribunal Superior de Justicia Electoral, sólo podrán ser sometidos a juicio político por mal desempeño de sus funciones, por delitos cometidos en el ejercicio de sus cargos o por delitos comunes. La acusación será formulada por la Cámara de Diputados, por mayoría de dos tercios.
}

Corresponderá a la Cámara de Senadores, por mayoría absoluta de dos tercios, juzgar em juicio público a los acusados por la Cámara de Diputados y, en caso, declararlos culpables, al sólo efecto 
FREITAS, Raquel Coelho de. A UNASUL e o papel da democracia nos países da América do Sul. Revista Eletrônica Direito e Política, Programa de Pós-Graduação Stricto Sensu em Ciência Jurídica da UNIVALI, Itajaí, v.11, n.1, $1^{\circ}$ quadrimestre de 2016. Disponível em: www.univali.br/direitoepolitica - ISSN 1980-7791.

Parlamento, se este cometer delitos previstos anteriormente na respectiva constituição ou em leis aprovadas pelos congressistas ou se este obtiver um mau desempenho de suas funções que deverá ser comprovado por métodos processuais que garantam a ampla defesa e o contraditório. Os cinco motivos apresentados abaixo sustentaram a alegação dos deputados de mau desempenho das funções presidenciais.

Na resolução ${ }^{17}$ proferida pela Câmara dos Deputados, foram elencados todos os fatos que motivaram a acusação contra Lugo:

a. $\quad 1.1$ Ato político no comando de engenharia das Forças Armadas

Em 2009, com autorização do Presidente Lugo, realizou-se uma concentração política de jovens no Comando de Engenharia das Forças Armadas, que foi financiado por instituições do Estado, inclusive pela Entidade Binacional Yacyreta. [...]

As instalações foram utilizadas para a reunião dos jovens, que ergueram bandeiras com alusões políticas, chegando a hastear uma delas no lugar da bandeira nacional.

Esse ato, de natureza claramente política cuja incivilidade foi amplamente divulgada pelos meios de comunicação, realizou-se com a autorização do Comandante em Chefe, e a prova de que o Governo apoiou, instigou e facilitou esses atos políticos no quartel é que vários funcionários importantes do Governo participaram do evento, proferindo discursos instigando a luta de classes. ${ }^{18}$

de separarlos de sus cargos, En los casos de supuesta comisión de delitos, se pasarán los antecedentes a la justicia ordinaria.

17 PARAGUAI. Congresso. Câmara dos Deputados. Resolución n. 1431, de 2012. Mediante a qual a egrégia Câmara dos Deputados da República do Paraguai dispõe sobre o libelo acusatório contra o presidente da república, Fernando Lugo Méndez. Disponível em: <http://www.ultimahora.com/adjuntos/imagenes/000/432/0000432478.pdf>. Acesso em: 05 set. 2012.

18 Tradução Livre: "En el año 2009, con autorización del Presidente Lugo, se realizó una concentración política de jóvenes en el Comando de Ingeniería de las Fuerzas Armadas, el que fue financiado por instituciones del Estado, incluyendo a la Entidad Binacional Yacyreta. [...] Esas instalaciones fueron utilizadas para la reunión de los jóvenes, quienes colgaron banderas con alusiones políticas, llegando a izarse una de ellas en sustitución del pabellón patrio. Ese acto de naturaleza netamente política y con los exabruptos ampliamente difundidos por los medios de prensa solo pudo ser realizado con la autorización del Comandante en Jefe y prueba de que el Gobierno avaló, instigó y facilitó esos actos políticos dentro del cuartel es que varios importantes funcionarios del Gobierno participaron del evento pronunciando discursos instigando a la lucha de clases." 
FREITAS, Raquel Coelho de. A UNASUL e o papel da democracia nos países da América do Sul. Revista Eletrônica Direito e Política, Programa de Pós-Graduação Stricto Sensu em Ciência Jurídica da UNIVALI, Itajaí, v.11, n.1, $1^{\circ}$ quadrimestre de 2016. Disponível em: www.univali.br/direitoepolitica - ISSN 1980-7791.

a. $\quad$ 1.2 Caso Ñacunday

O Governo do Presidente Lugo foi o único responsável, como instigador e facilitador, pelas recentes invasões de terras em Nacunday. A falta de resposta das forças policiais diante das invasões de bens de domínio privado por supostos carperos (acampados) e sem-terra foi apenas uma parte dessa conduta cúmplice.

O Presidente Lugo utilizou as forças militares para gerar uma situação de verdadeiro pânico em toda a região, violando o direito de propriedade e ingressando em imóveis de colonos sob o pretexto de realizar o trabalho de demarcação da faixa de exclusão de fronteira.

Fernando Lugo submeteu as forças militares aos denominados carperos, que realizaram todo tipo de abusos, agressões e ataques à propriedade privada, bem diante das forças públicas, que não atuaram devido à indissimulável cumplicidade do Presidente da República com esses agressores. ${ }^{19}$

a. $\quad 1.3$ Crescente insegurança

Nesses quatro anos de Governo, apesar dos consideráveis recursos financeiros que Ihe foram proporcionados pelo Congresso Nacional a fim de intensificar a força pública, os resultados foram não apenas insatisfatórios, mas também ficou mais do que demonstrada a falta de vontade do Governo para combater o Exército do Povo Paraguaio (EPP), que se converteu, com o apoio e a cumplicidade do Governo, em flagelo para os cidadãos dos departamentos de Concepción e San Pedro.

O Presidente Lugo é responsável pela crescente insegurança e é responsável também por ter mantido, por tanto tempo, como Ministro do Interior, uma pessoa absolutamente inapta e incapaz para o cargo. Essa inaptidão, somada à

\footnotetext{
19 Tradução Livre: "Fue el Gobierno del Presidente Lugo el único responsable como instigador y facilitador de las recientes invasiones de tierras en la zona de Ñacunday. La falta de respuesta de las fuerzas policiales ante las invasiones de supuestos carperos y sin tierras a bienes del dominio privado, solo han sido parte de esa conducta cómplice. El presidente Lugo ha utilizado a las fuerzas militares para generar un verdadero estado de pánico en toda esa región, violando el derecho de propiedad e ingresando a inmuebles de colonos, so pretexto de realizar el trabajo de amojonamiento de la franja de exclusión fronteriza. Fernando Lugo ha sometido las fuerzas militares a los denominados carperos, quienes han realizado todo tipo de abusos, agresiones y atracos a la propiedad privada, a la vista de las fuerzas públicas, quienes no actuaron por la indisimulada complicidad del Presidente de la República con esos agresores."
} 
FREITAS, Raquel Coelho de. A UNASUL e o papel da democracia nos países da América do Sul. Revista Eletrônica Direito e Política, Programa de Pós-Graduação Stricto Sensu em Ciência Jurídica da UNIVALI, Itajaí, v.11, n.1, $1^{\circ}$ quadrimestre de 2016. Disponível em: www.univali.br/direitoepolitica - ISSN 1980-7791.

indissimulável relação de cumplicidade entre o Presidente Lugo e os líderes da associação de carperos e de outras organizações que foram protagonistas de inúmeras invasões de terras e de outros tipos de agressões, propiciaram e facilitaram o lamentável evento que custou a vida de 17 compatriotas, seis deles integrantes da Polícia Nacional, e que foram cruelmente assassinados, a sangue frio, por verdadeiros criminosos, os quais, além disso, incitaram e manipularam agricultores da região. $[\ldots]^{20}$

a. 1.4 Protocolo de Ushuaia II

Esse documento constitui um ATENTADO CONTRA A SOBERANIA da República do Paraguai e foi subscrito pelo Presidente FERNANDO LUGO MÉNDEZ com o propósito perverso de obter um suposto apoio à sua descarada marcha contra a institucionalidade e o processo democrático da República.

[...] Por meio desse documento, os países vizinhos poderiam cortar o fornecimento de energia à República do Paraguai.

O principal aspecto do Protocolo de Ushuaia II consiste na identificação do Estado com a figura dos presidentes para, em nome da "defesa da democracia", defenderem uns aos outros. ${ }^{21}$

\footnotetext{
20 Tradução Livre: "En estos 4 años de Gobierno, a pesar de los importantes recursos financieros que le fueron proveídos por el Congreso Nacional para potenciar a la fuerza pública, los resultados han sido no solo insatisfactorios sino también ha quedado por demás demostrado la falta de voluntad del Gobierno para combatir al Ejercito del Pueblo Paraguayo, que se ha convertido, al amparo y con la complicidad del Gobierno, en el azote de los ciudadanos de los departamentos de Concepción y San Pedro. El Presidente Lugo es el responsable de la creciente inseguridad y es responsable también por haber mantenido por tanto tiempo como Ministro del Interior a una persona absolutamente inepta e incapaz para ocupar ese cargo. Esa ineptitud, sumada a la indisimulada relación cómplice entre el Presidente Lugo y los líderes de la asociación de carperos y otras organizaciones que fueron protagonistas de innumerables invasiones de tierras y otros tipos de agresiones son los que han propiciado y facilitado el lamentable suceso que costara la vida a 17 compatriotas, 6 de ellos pertenecientes a la Policía Nacional y que fueron cruelmente asesinados y a sangre fría por auténticos criminales, que también han incitado y manipulado a campesinos del lugar. $[\ldots]$

21 Tradução Livre: "Este documento constituye UN ATENTADO CONTRA LA SOBERANÍA de la República del Paraguay y ha sido suscrito por el Presidente FERNANDO LUGO MENDEZ con el avieso propósito de obtener un supuesto respaldo en su descarada marcha contra la institucionalidad y el proceso democrático de la República.
}

[...] A través de ese documento, los países vecinos podrían cortar el suministro de energía a la República del Paraguay.

La principal característica del Protocolo de Ushuaia II es la identificación del Estado com la figura de los presidentes para, en el nombre de la "defensa de la democracia", defenderse unos a otros." 
FREITAS, Raquel Coelho de. A UNASUL e o papel da democracia nos países da América do Sul. Revista Eletrônica Direito e Política, Programa de Pós-Graduação Stricto Sensu em Ciência Jurídica da UNIVALI, Itajaí, v.11, n.1, $1^{\circ}$ quadrimestre de 2016. Disponível em: www.univali.br/direitoepolitica - ISSN 1980-7791.

a. $\quad 1.5$ Massacre de Curuguaty

Não há dúvida de que a responsabilidade política e criminal dos trágicos eventos registrados em 15 de junho deste ano, que custaram a vida de 17 cidadãos paraguaios, entre policiais e agricultores, recaia sobre o Presidente da República, Fernando Lugo, que, devido à sua inércia e incompetência, ocasionou os fatos sucedidos, de conhecimento público, os quais não precisam ser provados por serem fatos públicos e notórios.

O incidente não surgiu espontaneamente, tendo sido uma emboscada às forças de segurança; foi premeditado, produto de um plano devidamente concebido, elaborado e executado graças à cumplicidade e inação do Governo de Fernando Lugo, responsável direto pela crise que nossa amada pátria hoje enfrenta. [...]

Fernando Lugo é o responsável direto pelo luto hoje vivenciado por nosso país. Tanto o Presidente como seu inábil ex-ministro do Interior, Carlos Filizzola, devem responder perante os cidadãos pelos trágicos acontecimentos verificados no departamento de Canindeyú.

Não existe disposição alguma de combater essas formas de violência, que tantos danos causaram à nossa sociedade, e, por esse motivo, devemos cumprir nossa obrigação constitucional e iniciar o processo de julgamento político por má gestão contra o Presidente da República que, desde que assumiu o Governo, incentivou o não cumprimento de ordens judiciais de desocupação, bem como a promoção de medições judiciais sem mediação jurídica entre as partes e o fornecimento de provisões e equipamentos aos ocupantes de terras; os quais marcaram suas ações e o espírito desse Governo. ${ }^{22}$

22 Tradução Livre: "No cabe duda que la responsabilidad política y penal de los trágicos eventos registrados 15 de junio del presente año, que costó la vida de 17 ciudadanos paraguayos entre policías y campesinos, recae en el Presidente de la República, Fernando Lugo, que por su inacción e incompetencia, dieron lugar a los hechos acaecidos, de conocimientos públicos, los cuales no necesitan ser probados, por ser hechos públicos y notorios.

El incidente no surgió espontáneamente, fue una emboscada a las fuerzas de seguridad; fue algo premeditado, producto de un plan debidamente concebido, planificado y llevado a la práctica, gracias a la complicidad e inacción del Gobierno de Fernando Lugo, responsable directo de la crisis que hoy atraviesa nuestra amada Patria.

Fernando Lugo es el directo responsable de que hoy nuestro país este viviendo días de luto. Tanto él como su incapaz ex Ministro del Interior Carlos Filizzola, deben responder ante la ciudadanía por los trágicos acontecimientos registrados en el Departamento de Canindeyú. 
FREITAS, Raquel Coelho de. A UNASUL e o papel da democracia nos países da América do Sul. Revista Eletrônica Direito e Política, Programa de Pós-Graduação Stricto Sensu em Ciência Jurídica da UNIVALI, Itajaí, v.11, n.1, $1^{\circ}$ quadrimestre de 2016. Disponível em: www.univali.br/direitoepolitica - ISSN 1980-7791.

Observa-se nas acusações a ausência de um motivo concreto que pudesse causar a crise política pela qual o Paraguai passou. Na verdade, a oposição se aproveitou dos trágicos acontecimentos que ocorreram no mandato de Lugo para justificar o impeachment impetrado contra ele.

Apesar de constitucional, o impeachment de Fernando Lugo foi antidemocrático. O presidente do Paraguai, eleito democraticamente pelo povo, foi destituído de seu cargo sem ter o seu direito à defesa e ao devido processo legal garantidos na Constituição. Além disso, não houve nenhum tipo de consulta popular para uma decisão dessa natureza. Por essas razões, o processo de impeachment impetrado pelo poder legislativo paraguaio passou a ser reconhecido como um golpe da oposição travestido de ato legal. Assim é que em 22 de junho de 2012, o Senado Paraguaio aprovou, com 39 votos a favor da condenação, o impeachment do presidente, assumindo, no mesmo dia, o vice, Federico Franco.

\section{4.b. PARAguAI e MERCOSUL}

Sete dias após a destituição de Fernando Lugo, os países integrantes do bloco econômico MERCOSUL, o qual o Paraguai também é membro, decidiram, unanimemente, suspender a participação do Paraguai nas atividades dos órgãos do MERCOSUL, suspendendo, também, o direito de votar e de vetar nas deliberações do bloco. O referido país somente poderá ser incorporado novamente ao MERCOSUL após as eleições presidenciais que ocorrerão em abril de 2013.

A decisão proferida pelos Estados-parte sustenta a suspensão do dito país no Protocolo de Montevidéu sobre Compromisso com a Democracia no MERCOSUL (Protocolo de Ushuaia II) que foi assinado por todos os Estados membros do

No existe voluntad alguna de combatir estas formas de violencia, que tanto daño ya há causado a nuestra sociedad, es por ello que debemos de cumplir con nuestra obligación Constitucional, e iniciar el proceso de juicio político por mal desempeño contra el Presidente de la República, quien desde que asumió el Gobierno ha instado al incumplimiento de órdenes judiciales de desalojo, así como a la promoción de mensuras judiciales sin mediar juicio entre las partes, o abasteciendo de provisiones y enseres a los ocupantes de tierras han sido los signos que marcaron las acciones y el temperamento de este Gobierno." 
FREITAS, Raquel Coelho de. A UNASUL e o papel da democracia nos países da América do Sul. Revista Eletrônica Direito e Política, Programa de Pós-Graduação Stricto Sensu em Ciência Jurídica da UNIVALI, Itajaí, v.11, n.1, $1^{\circ}$ quadrimestre de 2016. Disponível em: www.univali.br/direitoepolitica - ISSN 1980-7791.

MERCOSUL, inclusive pelo Paraguai, onde se comprometem a manter a democracia dentro de seus territórios, sendo esta a condição necessária para o desenvolvimento do processo integracionista na América do Sul ${ }^{23}$.

O Protocolo de Ushuaia II (PU), de acordo com o artigo $1^{\circ}$, somente pode ser aplicado em caso de ruptura ou ameaça de ruptura da ordem democrática dentro dos países signatários. No artigo $6^{\circ}$ do Protocolo, são elencadas algumas medidas sancionadoras: suspensão do direito de participar dos órgãos do MERCOSUL; bloqueio total ou parcial das fronteiras terrestres; suspensão dos direitos e benefícios emergentes dos tratados, protocolos e acordos de integração celebrados entre os países membros; suspensão ou limitação do comércio, do fornecimento de energia, serviços e abastecimento, entre outras medidas sancionadoras de caráter político e diplomático ${ }^{24}$. Ainda de acordo com o artigo 60 ,

As medidas guardarão a devida proporcionalidade com a gravidade da situação existente; não deverão pôr em risco o bem-estar da população e o gozo efetivo dos direitos humanos e liberdades fundamentais na Parte afetada; respeitarão a soberania e integridade territorial da Parte afetada, a situação dos países sem litoral marítimo e os tratados vigentes ${ }^{25}$.

A decisão que suspendeu o Paraguai do MERCOSUL ${ }^{26}$ foi bastante clara ao afirmar "que tal suspensão não diminui o compromisso com o bem-estar e o desenvolvimento do Paraguai nem deve produzir prejuízo algum ao povo

\footnotetext{
${ }^{23}$ MERCOSUL. Protocolo de Montevidéu sobre Compromisso com a Democracia no Mercosul (Ushuaia II). Disponível em:

<http://www.mercosur.int/innovaportal/file/2486/1/ushuaia_ii.pdf>. Acesso em: 06 set. 2012.

24 MERCOSUL. Protocolo de Montevidéu sobre Compromisso com a Democracia no Mercosul (Ushuaia II). Disponível em:

<http://www.mercosur.int/innovaportal/file/2486/1/ushuaia_ii.pdf>. Acesso em: 06 set. 2012.

25 MERCOSUL. Protocolo de Montevidéu sobre Compromisso com a Democracia no Mercosul (Ushuaia II). Disponível em:

<http://www.mercosur.int/innovaportal/file/2486/1/ushuaia_ii.pdf>. Acesso em: 06 set. 2012.

26 MERCOSUL. Decisión sobre la suspensión del Paraguay en el Mercosul en aplicación del Protocolo de Ushuaia sobre Compromiso Democrático. Disponível em: <http://www.mercosur.int/innovaportal/file/4496/1/ver_adjunto.pdf>. Acesso em: 06 set. 2012.
} 
FREITAS, Raquel Coelho de. A UNASUL e o papel da democracia nos países da América do Sul. Revista Eletrônica Direito e Política, Programa de Pós-Graduação Stricto Sensu em Ciência Jurídica da UNIVALI, Itajaí, v.11, n.1, $1^{\circ}$ quadrimestre de 2016. Disponível em: www.univali.br/direitoepolitica - ISSN 1980-7791.

paraguaio"27 quando, apesar da suspensão, garantiu ainda ao Paraguai o recebimento de verbas do Fundo de Convergência Estrutural do MERCOSUL $(\text { FOCEM) })^{28}$.

A adesão da Venezuela ao MERCOSUL ocorreu de forma tão rápida quanto o impeachment de Fernando Lugo. Em 30 de julho de 2012, durante a X Reunião Extraordinária do Conselho do Mercado $C^{2}$ omum ${ }^{29}$, a decisão que estabelecia a entrada da Venezuela no MERCOSUL foi aprovada, oficializando, assim, a sua adesão em 12 de agosto de 2012, quando a Venezuela adquiriria a condição de Estado-Parte.

O ingresso da Venezuela ao bloco dependia somente da aprovação do Senado paraguaio, processo que tramitou por, aproximadamente, seis anos. Argentina, Brasil e Uruguai decidiram pela incorporação do referido país ao MERCOSUL, porém o parlamento paraguaio determinou pela rejeição da Venezuela como membro pleno do bloco. De acordo com o senador José Guastella, o Paraguai não poderia apoiar o "caráter autoritário, ditatorial do governo de Hugo Chávez". Devido à suspensão, a rejeição do Paraguai também precisou ser suspensa, valendo-se apenas das decisões dos outros três Estados-Parte.

O Paraguai, em nove de julho de 2012, pediu a revisão da decisão de suspensão do país do MERCOSUL e a anulação da decisão de ingresso da Venezuela ao bloco. No laudo do Tribunal Permanente de Revisão do Mercado Comum do Sul (TPR) proferido no dia 21 de julho de 2012, foram apresentadas as motivações do Paraguai que o levaram a recorrer ao TPR:

\footnotetext{
27 MERCOSUL. Decisión sobre la suspensión del Paraguay en el Mercosul en aplicación del Protocolo de Ushuaia sobre Compromiso Democrático. Disponível em:

<http://www.mercosur.int/innovaportal/file/4496/1/ver_adjunto.pdf>. Acesso em: 06 set. 2012.

28 O FOCEM é um Fundo destinado a financiar projetos em benefício das economias menores do MERCOSUL. (...) Os objetivos do Fundo são promover a convergência estrutural; desenvolver a competitividade; promover a coesão social, em particular das economias menores e regiões menos desenvolvidas, e apoiar o funcionamento da estrutura institucional e o fortalecimento do processo de integração. Disponível em: <http://www.mercosur.int/show?contentid=469\&channel=secretaria >. Acesso em: 06 set. 2012.

29 MERCOSUL. X Reunião Extraordinária do Conselho do Mercado Comum. Disponível em: <http://www.mercosur.int/innovaportal/file/4537/1/ata_cmc_01_-_12.pdf>. Acesso em: 11 set. 2012.
} 
FREITAS, Raquel Coelho de. A UNASUL e o papel da democracia nos países da América do Sul. Revista Eletrônica Direito e Política, Programa de Pós-Graduação Stricto Sensu em Ciência Jurídica da UNIVALI, Itajaí, v.11, n.1, $1^{\circ}$ quadrimestre de 2016. Disponível em: www.univali.br/direitoepolitica - ISSN 1980-7791.

11. Paraguai, em sua apresentação, alega que a gravidade das medidas adotadas na reunião de Cúpula de Presidentes causa dano irreparável por impedirem estas o exercício de seus direitos soberanos e inalienáveis como Estado fundador do MERCOSUL.

12. Sustenta que a referida suspensão não se instrumentalizou mediante norma emanada dos órgãos enunciados no Protocolo Ouro Preto (adiante POP) nem por meio da aplicação das fontes jurídicas enunciadas no art. 41 do POP. Questiona a legitimidade dos Chefes de Estado para adotar decisões obrigatórias em razão de que as Reuniões de Cúpula presidenciais não constituem e nem integram os órgãos do MERCOSUL e que suas decisões não se ajustam à sua normativa da organização.

13. Paraguai considera que não houve ruptura da ordem democrática e que não se realizaram as consultas previstas no artigo 40 do $\mathrm{PU}$.

14. Os argumentos da demanda relacionados à incorporação da Venezuela como membro pleno incluem a ausência de participação do Paraguai como membro pleno do MERCOSUL, os direitos e obrigações do Paraguai como depositário do Protocolo de Adesão, a falta da unanimidade requerida para a tomada de decisões segundo o artigo 20 do Tratado de Assunção (adiante TA) e inobservância do art. 40 do POP sobre vigência simultânea das normas emanadas dos órgãos do MERCOSUL. Enumera, também, uma série de normas e princípios de direito internacional que considera haverem sido violadas por essa decisão, como a Convenção de Viena sobre Direito dos Tratados de 1969.

15. Paraguai considera que as decisões objeto da demanda padecem de falta de motivação carecendo, por este motivo, de validade jurídica, e que as mesmas geram responsabilidade internacional por não cumprirem regras convencionais do TA, do POP, do PU e de outras normas e princípios de direito internacional ${ }^{30}$.

A alegação paraguaia consiste, portanto, na inobservância dos tratados e protocolos do MERCOSUL; na violação das normas e princípios de direito

${ }^{30}$ MERCOSUL. Laudo do Tribunal Permanente de Revisão no procedimento excepcional de urgência solicitado pela República do Paraguai em relação à suspensão de sua participação nos órgãos do Mercado Comum do Sul (MERCOSUL) e à incorporação da Venezuela como membro pleno. Disponível em: <http://www.mercosur.int/innovaportal/file/440/1/laudo_01_2012_pt.pdf>. Acesso em: 13 set. 2012. 
FREITAS, Raquel Coelho de. A UNASUL e o papel da democracia nos países da América do Sul. Revista Eletrônica Direito e Política, Programa de Pós-Graduação Stricto Sensu em Ciência Jurídica da UNIVALI, Itajaí, v.11, n.1, $1^{\circ}$ quadrimestre de 2016. Disponível em: www.univali.br/direitoepolitica - ISSN 1980-7791.

internacional; no não reconhecimento de alguns direitos do Paraguai que são inalienáveis devido à sua condição de Estado-Parte; entre outros pretextos. Argentina, Brasil e Uruguai contestam com sucesso as alegações do Paraguai:

18. Alegam os Estados-Parte demandados que a democracia seria condição sine qua non para o desenvolvimento do processo de integração, que o PU fugiria do sistema de solução de controvérsias do MERCOSUL e representaria a norma-base do processo de integração, da qual derivaria a legitimidade dos Estados para integrarem o MERCOSUL.

19. Nesse sentido, sustentam que a decisão de suspender o Paraguai em seu direito de participar dos órgãos do MERCOSUL, com base no art. $5^{\circ}$ do $\mathrm{PU}$, não poderia ser examinada pelo TPR, motivo pelo qual requerem que este se declare incompetente em razão da matéria.

20. Uma segunda questão preliminar apresentada seria a inadequação da via eleita, posto que o procedimento para casos excepcionais de urgência do art. 24 do PO não se aplicaria ao objeto da apresentação do Paraguai. Esta medida teria sido prevista estritamente para casos específicos de natureza comercial e sua viabilidade dependeria do cumprimento dos requisitos cumulativos enunciados na norma, os quais não se aplicariam a esta ação.

21. Uma terceira questão preliminar apresentada seria a ausência de negociações diretas e de consentimento para o exercício da competência originária do TPR conforme o artigo 23 do PO. Afirmam que o Paraguai não demonstrou haver tentado realizar negociações diretas e que os demandados não apresentaram consentimento para iniciar o acesso direto ao TPR.

23. Além disso, os demandados sustentam a legalidade da suspensão do Paraguai em razão de haverem realizado consultas prévias com diversos atores políticos paraguaios, aos quais foi solicitado que se respeitassem o direito de defesa e a garantia do devido processo.

24. Sustentam a competência dos Chefes de Estado para adotar a decisão de suspensão em virtude de o PU nada estabelecer a respeito. Por sua vez, ressaltaram a proporcionalidade da medida, a qual teria sido a menos gravosa possível e de caráter provisório. A natureza da decisão adotada seria política, razão pela qual não se faria necessária a realização de um processo com contraditório para que fosse emitida. 
FREITAS, Raquel Coelho de. A UNASUL e o papel da democracia nos países da América do Sul. Revista Eletrônica Direito e Política, Programa de Pós-Graduação Stricto Sensu em Ciência Jurídica da UNIVALI, Itajaí, v.11, n.1, $1^{\circ}$ quadrimestre de 2016. Disponível em: www.univali.br/direitoepolitica - ISSN 1980-7791.

25. Sustentam os demandados que no Paraguai produziu a ruptura da ordem democrática em razão de a destituição do Presidente Fernando Lugo Méndez haver sido realizada mediante procedimento sumaríssimo, sem respeitar as garantias do devido processo.

26. Em relação à legalidade da declaração de incorporação da Venezuela, diferenciam dois atos: a aprovação da solicitação de adesão e a declaração de incorporação de um novo membro. A primeira, prevista no art. 20 do TA, que requer unanimidade, e a segunda, de caráter declaratório, que não necessita unanimidade. O protocolo de adesão da Venezuela, afirmam, entrará em vigor 30 dias depois da data de depósito do último instrumento de ratificação dos Estados-Partes não suspensos. A participação do Paraguai nessas decisões, em seu caráter suspenso, tornaria ineficaz o PU.

27. Argentina, Brasil e Uruguai solicitam ao TPR que se rejeite o presente procedimento sem julgar o mérito em razão da incompetência ratione materiae do TPR por se tratar de um litígio de natureza política não alcançado pelo sistema de solução de controvérsias previsto no PO ou, em caráter subsidiário, por não ser aplicável o PO para dirimir conflitos que resultam da aplicação do PU; porque a via eleita do procedimento para atender casos excepcionais de urgência seria inadequada; e pela incompetência do TPR devida à falta de consentimento para o exercício da competência originária do art. 23 do PO. No caso de que as questões preliminares não sejam conhecidas, os demandados solicitam que se decida pela improcedência da apresentação tanto no que se refere ao pedido de cancelamento da suspensão do Paraguai de participar dos órgãos do MERCOSUL, quanto ao pedido de suspensão dos efeitos da Declaração sobre a Incorporação da República Bolivariana da Venezuela ao MERCOSUL ${ }^{31}$.

Em três dias de julgamento, decidiu-se que:

1. Por unanimidade, em conformidade com as considerações anteriores, o Tribunal Permanente de Revisão decide, em relação ao requerimento dos demandados relacionado à

\footnotetext{
31 MERCOSUL. Laudo do Tribunal Permanente de Revisão no procedimento excepcional de urgência solicitado pela República do Paraguai em relação à suspensão de sua participação nos órgãos do Mercado Comum do Sul (MERCOSUL) e à incorporação da Venezuela como membro pleno. Disponível em:

<http://www.mercosur.int/innovaportal/file/440/1/laudo_01_2012_pt.pdf>. Acesso em: 13 set. 2012.
} 
FREITAS, Raquel Coelho de. A UNASUL e o papel da democracia nos países da América do Sul. Revista Eletrônica Direito e Política, Programa de Pós-Graduação Stricto Sensu em Ciência Jurídica da UNIVALI, Itajaí, v.11, n.1, $1^{\circ}$ quadrimestre de 2016. Disponível em: www.univali.br/direitoepolitica - ISSN 1980-7791.

incompetência ratione materiae, que a jurisdição do sistema de solução de controvérsias do MERCOSUL abarca o exame de legalidade da aplicação do Protocolo de Ushuaia.

2. Por unanimidade, o Tribunal Permanente de Revisão decide que não estão presentes os requisitos para a admissibilidade do procedimento excepcional de urgência regulamentado na Decisão 23/04.

4. Por unanimidade, ao adotar esta decisão sem ingressar na análise de mérito da demanda, o Tribunal Permanente de Revisão não se pronuncia sobre cumprimento ou violação da normativa MERCOSUL relacionada à demanda apresentada neste procedimento. A presente decisão não inibe outros meios, aos quais possam recorrer os Estados-Parte no marco do sistema de solução de controvérsias do MERCOSUL ${ }^{32}$.

A falta de um pronunciamento do Tribunal Permanente de Revisão não esclareceu a decisão do tribunal diante do que foi pedido pelo Paraguai. Podemos, assim, concluir que a suspensão do Paraguai e a adesão da Venezuela no MERCOSUL permanecem com força normativa para o bloco em questão.

Segundo José Augusto Fontoura Costa,

O afastamento temporário do Paraguai não lhe retira a condição de membro nem permite nenhuma forma de adesão que prescinda da expressão positiva de sua vontade. Da maneira como foi feita, a adesão da Venezuela - já aprovada no Brasil há muito e desejável sob vários pontos de vista - ocorreu fora da regularidade jurídica do MERCOSUL. É difícil afirmar que tal atitude promova a democracia. ${ }^{33}$

\section{4.c. PARAGUAI E UNASUL}

\footnotetext{
32 MERCOSUL. Laudo do Tribunal Permanente de Revisão no procedimento excepcional de urgência solicitado pela República do Paraguai em relação à suspensão de sua participação nos órgãos do Mercado Comum do Sul (MERCOSUL) e à incorporação da Venezuela como membro pleno. Disponível em: <http://www.mercosur.int/innovaportal/file/440/1/laudo_01_2012_pt.pdf>. Acesso em: 13 set. 2012.

${ }^{33}$ COSTA, José Augusto Fontoura. Poder e legalidade no Mercosul, São Paulo, 11 jul. 2012. Disponível em: <http://www.estadao.com.br/noticias/impresso,poder-e-legalidade-no-mercosul,898602,0.htm>. Acesso em: 14 set. 2012.
} 
FREITAS, Raquel Coelho de. A UNASUL e o papel da democracia nos países da América do Sul. Revista Eletrônica Direito e Política, Programa de Pós-Graduação Stricto Sensu em Ciência Jurídica da UNIVALI, Itajaí, v.11, n.1, $1^{\circ}$ quadrimestre de 2016. Disponível em: www.univali.br/direitoepolitica - ISSN 1980-7791.

Em 29 de junho de 2012, os países membros da União das Nações SulAmericanas decidiram, em uma reunião extraordinária do conselho de chefes de Estado e de Governo da UNASUL ${ }^{34}$, pela suspensão do Paraguai do bloco. Esta decisão baseou-se na ruptura da ordem democrática provocada, no Paraguai, com o impeachment de Lugo, presidente democraticamente eleito pelo povo em 2008.

Os Estados membros da UNASUL decidiram por:

1. Expressar sua mais firme condenação à ruptura da ordem democrática na República do Paraguai executado mediante um procedimento sumaríssimo que evidenciou uma clara violação do direito ao devido processo legal e, em consequência, das mínimas garantias legais para sua adequada defesa.

2. Adotar a decisão política baseada no Tratado Constitutivo da UNASUL de suspender a República do Paraguai das participações nos órgãos e instâncias da União, até que este Conselho revogue a suspensão ${ }^{35}$.

3.

O Protocolo Adicional ao Tratado Constitutivo da UNASUL ${ }^{36}$ sobre Compromisso com a Democracia precisou ser acionado, de acordo com o artigo 10, devido à quebra da democracia que levou o país a ser suspenso. A suspensão encontrou embasamento no inciso " $a$ " do artigo 40 deste mesmo Protocolo, em cumprimento aos objetivos de proteção de um modelo democrático que atenda, de fato, às necessidades dos mais excluídos da região.

\footnotetext{
${ }^{34}$ UNASUL. Reunión Extraordinaria del Consejo de Jefas y Jefes de Estado y de Gobierno de Unasur. Disponível em: $<$ http://www.unasursg.org/index.php?option=com_content\&view $=$ article\&id=701\%3Adecisionn26-2012-reunion-extraordinaria-de-jefas-y-jefes-de-estado-mendoza-junio-292012\&catid=72\%3Aorganos\&Itemid=342>. Acesso em: 14 set. 2012.
}

35 "1. Expresar su más enérgica condena a la ruptura del orden democrático en la República del Paraguay, ejecutado mediante un procedimiento sumarísimo que evidenció uma clara violación del derecho al debido proceso y, en consecuencia, de las mínimas garantías para su adecuada defensa; 2. Adoptar la decisión política basada en el tratado constitutivo de UNASUR, de suspender a la República del Paraguay de participar en los órganos e instancias de la Unión, hasta tanto este Consejo revoque la suspensión."

36 UNASUL. Protocolo Adicional ao Tratado Constitutivo da Unasul sobre Compromisso com a Democracia. Disponível em: <http://www.itamaraty.gov.br/temas/america-do-sul-eintegracao-regional/unasul/protocolo-adicional-ao-tratado-constitutivo-da-unasul-sobrecompromisso-com-a-democracia>. Acesso em: 14 set. 2012. 
FREITAS, Raquel Coelho de. A UNASUL e o papel da democracia nos países da América do Sul. Revista Eletrônica Direito e Política, Programa de Pós-Graduação Stricto Sensu em Ciência Jurídica da UNIVALI, Itajaí, v.11, n.1, $1^{\circ}$ quadrimestre de 2016. Disponível em: www.univali.br/direitoepolitica - ISSN 1980-7791.

\section{CONSIDERAÇÕES FINAIS}

O Constitucionalismo teve como berço a comunidade europeia. Logicamente, os preceitos constitucionalistas desenvolvidos se amoldaram às situações vividas em épocas específicas, pelos seus países daquele continente, países estes que costumeiramente possuíam um desenvolvimento econômico, político e social, bastante compatíveis entre si.

A importação de muitos desses valores e normas constitucionais para a América Latina, nem sempre conseguiu o êxito e legitimidade pretendidos. Os países latino-americanos foram condicionados a um determinado modelo democrático de Estado imposto pelos países "desenvolvidos" aos "subdesenvolvidos", sem levar em consideração as inúmeras diferenças existentes entre estes e aqueles. Por esse motivo, tornou-se cada vez mais urgente a necessidade que os países da América Latina passaram a apresentar em construir um novo modelo de Estado capaz de suprir as suas carências e se adequar às transformações políticas, econômicas e sociais surgidas ao longo do processo constituinte latinoamericano.

Segundo o constitucionalista Paulo Bonavides,

Do nosso ponto de vista, a democracia participativa nos países periféricos é, em tese, a guardiã política do constitucionalismo social; o meio, por excelência, de prevenir a ruína dos direitos fundamentais da segunda geração em face da ameaça supressiva que lhe faz o neoliberalismo. ${ }^{37}$

Assim, acredita-se que quanto mais participativo, mais legítimo é o modelo democrático para a América Latina, pois é através de mecanismos de democracia participativa e comunitária que se obtém uma participação popular mais forte e ativa dentro do Estado que a adere, expressando, assim, a vontade soberana do

37 BONAVIDES, Paulo. Constitucionalismo Social e Democracia Participativa. In: Congreso Internacional de Derecho Constitucional. VI Congreso Nacional de Derecho Constitucional, UNAM. México, 2006. Disponível em: <http://www.juridicas.unam.mx/sisjur/constit/pdf/6-234s.pdf>. Acesso em: 30 set. 2012. 
FREITAS, Raquel Coelho de. A UNASUL e o papel da democracia nos países da América do Sul. Revista Eletrônica Direito e Política, Programa de Pós-Graduação Stricto Sensu em Ciência Jurídica da UNIVALI, Itajaí, v.11, n.1, $1^{\circ}$ quadrimestre de 2016. Disponível em: www.univali.br/direitoepolitica - ISSN 1980-7791.

povo. As constituições que sofrem influência do novo constitucionalismo latinoamericano ou adotam a democracia participativa como modo de exercício da democracia direta, ou adotam outros mecanismos de participação potencializadores da opinião pública nos processos consultivos e deliberativos de importantes decisões nacionais.

Devido à falta de cultura democrática da região, é possível que a concretização da democracia participativa dentro dos países latino-americanos encontre obstáculos mais imediatos. A reversão desse quadro requer um compromisso tanto de Estado quanto de governos que possam se alternar, em respeito às novas normas constitucionais. Os governantes devem se mostrar comprometidos com as mudanças que deverão ser realizadas dentro do sistema político de governo para que estes se ajustem a uma nova era que já se inicia. Enquanto isso, as normas constitucionais precisam ser interpretadas à luz dos princípios democráticos, com o objetivo sempre de ampliar as possibilidades de uso dos mecanismos de democracia participativa dentro das constituições.

O caso do Paraguai, analisado anteriormente, é um exemplo dessa tentativa. Em seu artigo $1^{0}$ da Constituição ${ }^{38}$, que dispõe sobre a forma de Estado e de governo, o Paraguai adota a democracia representativa, participativa e pluralista . Entretanto, o que se observa é a ruptura com a ordem democrática paraguaia, um modelo democrático que fora legitimado constitucionalmente, porém, sem nenhuma efetividade. A crise política vivida pelos paraguaios decorre de uma interpretação constitucional equivocada dos parlamentares, uma interpretação que não obedeceu aos trâmites democráticos, ao quais, supostamente, deveriam reger a constituição como um todo.

Com isso, conclui-se com Bonavides quando este assevera:

38 PARAgUAI. Constituição (1992). Constituição da República do Paraguai. Disponível em: $<$ http://www.icrc.org/ihl-

nat.nsf/162d151af444ded44125673e00508141/70fa4404138f6d39c12570530030067c/\$FILE/Const itucion.Paraguay.ESP.pdf>. Acesso em: 29 set. 2012.

\section{Artículo 1 - DE LA FORMA DEL ESTADO Y DE GOBIERNO}

[...] La República del Paraguay adopta para su gobierno la democracia representativa, participativa y pluralista, fundada en el reconocimiento de la dignidad humana. 
FREITAS, Raquel Coelho de. A UNASUL e o papel da democracia nos países da América do Sul. Revista Eletrônica Direito e Política, Programa de Pós-Graduação Stricto Sensu em Ciência Jurídica da UNIVALI, Itajaí, v.11, n.1, $1^{\circ}$ quadrimestre de 2016. Disponível em: www.univali.br/direitoepolitica - ISSN 1980-7791.

A democracia caminha, a largos passos, para deixar de ser apenas forma de governo, de Estado, de república, de convivência humana e social, de regime, ou de sistema político, para subir a um grau superlativo de princípio, de valor e de normatividade, derivado de sua proclamação e reconhecimento como direito da quarta geração. ${ }^{39}$

\section{REFERÊNCIAS DAS FONTES CITADAS}

BARROSO, Luís Roberto. Curso de Direito Constitucional Contemporâneo: os conceitos fundamentais e a construção do novo modelo. $2^{a}$ edição. São Paulo: Saraiva, 2010.

BOLÍVIA. Constituição da República da Bolívia de 2009. Disponível em: <http://consuladoboliviano.com.ar/portal/node/119>. Acesso em: 29 set. 2012.

BONAVIDES, Paulo. Constitucionalismo Social e Democracia Participativa. In: Congreso Internacional de Derecho Constitucional. VI Congreso Nacional de Derecho Constitucional, UNAM. México, 2006. Disponível em: <http://www.juridicas.unam.mx/sisjur/constit/pdf/6-234s.pdf>. Acesso em: 30 set. 2012.

CANOTILHO, J. J. Direito Constitucional. 6 ed. Coimbra: Edições Almedina, 1993.

CANOTILHO, J. J. Direito constitucional e teoria da constituição. 7 ed. Coimbra: Edições Almedina. 2003.

CERVO, Amado Luiz. Relações internacionais da América Latina: velhos e novos paradigmas. Brasília: IBRI, 2001.

CESAR, R. C. L. A Unasul e o Processo de Integração Latino-americano. In: A Construção Jurídica da UNASUL. Florianópolis: Ed. Da UFSC: Fundação Boiteux, 2011.

COSTA, José Augusto Fontoura. Poder e legalidade no Mercosul, São Paulo, 11 jul. 2012. Disponível em: <http://www.estadao.com.br/noticias/impresso,poder-e-legalidade-no-mercosul,898602,0.htm>. Acesso em: 14 set. 2012.

DALLARI, Dalmo de Abreu. Elementos de teoria geral do estado. 2. ed. São Paulo: Saraiva, 1998.

GUASTINI, Riccardo. La constitucionalización del ordenamiento jurídico: el caso italiano, em Carbonell, M. Neoconstitucionalismo(s). Madrid: Trotta, 2003.

39 BONAVIDES, Paulo. Constitucionalismo Social e Democracia Participativa. In: Congreso Internacional de Derecho Constitucional. VI Congreso Nacional de Derecho Constitucional, UNAM. México, 2006. Disponível em: <http://www.juridicas.unam.mx/sisjur/constit/pdf/6-234s.pdf>. Acesso em: 30 set. 2012. 
FREITAS, Raquel Coelho de. A UNASUL e o papel da democracia nos países da América do Sul. Revista Eletrônica Direito e Política, Programa de Pós-Graduação Stricto Sensu em Ciência Jurídica da UNIVALI, Itajaí, v.11, n.1, $1^{\circ}$ quadrimestre de 2016. Disponível em: www.univali.br/direitoepolitica - ISSN 1980-7791.

MERCOSUL. Decisión sobre la suspensión del Paraguay en el Mercosul en aplicación del Protocolo de Ushuaia sobre Compromiso Democrático. Disponível em: <http://www.mercosur.int/innovaportal/file/4496/1/ver_adjunto.pdf>. Acesso em: 06 set. 2012.

. Laudo do Tribunal Permanente de Revisão no procedimento excepcional de urgência solicitado pela República do Paraguai em relação à suspensão de sua participação nos órgãos do Mercado Comum do Sul (MERCOSUL) e à incorporação da Venezuela como membro pleno. Disponível em: <http://www.mercosur.int/innovaportal/file/440/1/laudo_01_2012_pt.pdf>. Acesso em: 13 set. 2012. <http://www.mercosur.int/innovaportal/file/2486/1/ushuaia_ii.pdf>. Acesso em: 06 set. 2012.

Disponível . X Reunião Extraordinária do Conselho do Mercado Comum. <http://www.mercosur.int/innovaportal/file/4537/1/ata_cmc_01_-_12.pdf>. Acesso em: 11 set. 2012.

O'DONNELL, Guillermo. Análise do Autoritarismo Burocrático. RJ: Paz e Terra, 1990.

PARAGUAI. Congresso. Câmara dos Deputados. Resolución n. 1431, de 2012. Mediante a qual a egrégia Câmara dos Deputados da República do Paraguai dispõe sobre o libelo acusatório contra o presidente da república, Fernando Lugo Méndez. <http://www.ultimahora.com/adjuntos/imagenes/000/432/0000432478.pdf>. Acesso em: 05 set. 2012.

Disponível Constituição (1992). Constituição da República do Paraguai. nat.nf/162d151af444ded44125673e00508141/70fa4404138f6d39c1257053003 0067c/\$FILE/Constitucion.Paraguay.ESP.pdf>. Acesso em: 29 set. 2012.

SOARES, M. S. A. O Paraguai: um país desconhecido. In: Seminário América do Sul: América do Sul. - Brasília: Fundação Alexandre de Gusmão, 2008.

UNASUL. Protocolo Adicional ao Tratado Constitutivo da Unasul sobre Compromisso com a Democracia. Disponível em: <http://www.itamaraty.gov.br/temas/america-do-sul-e-integracaoregional/unasul/protocolo-adicional-ao-tratado-constitutivo-da-unasul-sobrecompromisso-com-a-democracia >. Acesso em: 14 set. 2012.

\footnotetext{
Reunión Extraordinaria del Consejo de Jefas y Jefes de Estado y de Gobierno de Unasur. Disponível em: <http://www.unasursg.org/index.php?option=com_content\&view=article\&id=70 1\%3Adecision-n26-2012-reunion-extraordinaria-de-jefas-y-jefes-de-estado-
} 
FREITAS, Raquel Coelho de. A UNASUL e o papel da democracia nos países da América do Sul. Revista Eletrônica Direito e Política, Programa de Pós-Graduação Stricto Sensu em Ciência Jurídica da UNIVALI, Itajaí, v.11, n.1, $1^{0}$ quadrimestre de 2016. Disponível em: www.univali.br/direitoepolitica - ISSN 1980-7791.

mendoza-junio-29-2012\&catid=72\%3Aorganos\&Itemid=342>. Acesso em: 14 set. 2012.

VICIANO, R. e MARTÍNEZ, R. Aspectos generales del nuevo constitucionalismo latinoamericano. In: Corte Constitucional de Ecuador para el período de transición.

El nuevo constitucionalismo en América Latina. 1 ed. Quito: Corte Constitucional del Ecuador, 2010.

. El nuevo constitucionalismo latinoamericano:

fundamentos para uma construcción doctrinal. In: Revista general de derecho público comparado, No. 9, 2011.

El proceso constituyente venezolano en el marco del nuevo constitucionalismo latinoamericano. In: Àgora - Revista de Ciencias Sociales, No. 13, 2005.

\section{SÍTIOS ELETRÔNICOS CONSULTADOS}

http://www.mercosur.int/show?contentid=469\&channel=secretaria http://pt.wikipedia.org/wiki/Fernando_Lugo

http://www.bbc.co.uk/portuguese/noticias/2012/06/120622_lugo_perfil_paragua i_mc.shtml

http://www.cartacapital.com.br/internacional/crise-politica-no-paraguai-umtestepara-a-regiao/

http://www.cartacapital.com.br/internacional/impeachment-de-fernando-lugofoisim-um-golpe/

http://www.zedirceu.com.br/index.php?option=com_content\&task=view\&\&id=16 152\&Itemid $=2$

http://enclave.com.br/?p=477

http://revistaepoca.globo.com/Mundo/noticia/2012/06/peter-lambert-

oimpeachment-

de-lugo-foi-legal-mas-nao-foi-democratico.html

Submetido em: Novembro de 2015.

Aprovado em: Fevereiro 2016. 